\title{
PENURUNAN INDEKS GINI PENDIDIKAN: INDONESIA, JAWA TENGAH DAN MAGELANG
}

\author{
Budiono \\ Bappeda dan Litbangda \\ Kabupaten Magelan \\ e-mail : berbudi480@ymail.com
}

\begin{abstract}
This policy paper aims to determine the relationship between educational inequality and the average length of schooling in Indonesia, Central Java Province and Magelang District. The data source is the national socio-economic survey (Susenas / BPS) in 2015 and 2020, especially the table: the percentage of the population aged 15 years and over according to the type of area and the highest level of education completed. To determine education inequality, it is calculated using data on the average length of schooling of the population aged 15 years and over, the Lorenz curve and the Gini index of education. The average length of schooling in Indonesia, Central Java Province, Magelang Regency increased during the 2015-2020 period, while education inequality decreased. The Gini index calculation results show that Indonesia is more evenly distributed than Central Java, and Magelang is the least even. A negative relationship was found between mean years of schooling and the Gini index of education. a positive relationship was found between the rate of increase in mean years of schooling and a decrease in the Gini index of education.
\end{abstract}

\begin{abstract}
ABSTRAK
Naskah kebijakan ini bertujuan untuk mengetahui hubungan antara ketimpangan pendidikan dengan rata-rata lama sekolah di Indonesia, Provinsi Jawa Tengah dan Kabupaten Magelang. Sumber data adalah surve social ekonomi nasional (Susenas / BPS) tahun 2015 dan 2020, khusunya tabel: persentase penduduk usia 15 tahun ke atas menurut tipe daerah dan jenjang pendidikan tertinggi yang ditamatkan. Untuk menentukan ketimpangan pendidikan dihitung melalui, data rata-rata lama sekolah penduduk usia 15 tahun ke atas, kurva Lorenz dan indeks Gini pendidikan. Rata-rata lama sekolah di Indonesia, Provinsi Jawa Tengah Kabupaten Magelang meningkat selama periode 2015-2020 sedangkan ketimpangan pendidikan menurun. Hasil perhitungan indeks gini menunjukan bahwa Indonesia lebih merata daripada Jawa Tengan, dan Magelang paling tidak merata. Hubungan negatif ditemukan antara ratarata tahun sekolah dan indeks Gini pendidikan. hubungan positif ditemukan antara tingkat kenaikan rata-rata tahun sekolah dan penurunan indeks Gini pendidikan..
\end{abstract}

Kata Kunci : Angka pendidikan, Ketimpangan pendidikan, Distribusi pendidikan, Rata-rata lama sekolah.

\section{PENDAHULUAN}

Penyelenggaraan pelayanan urusan pendidikan merupakan amanat konstitusi. Sesuai Pembukaan UUD 1945, mencerdaskan kehidupan bangsa merupakan 'tujuan' pembentukan pemerintahan negara, yang dijadikan 'visi' abadi pemerintahan negara. Selanjutnya, amanat terkait hak warga negara dan kewajiban pemenuhan pendidikan ditegaskan pada pasal 31 UUD 1945, ayat 1 hingga ayat 5. 


\section{Buletin Ekonomi}

Sebelumnya, pada pasal 28 UUD 1945, ditegaskan bahwa 'pendidikan' merupakan hak azasi manusia, sebagai berikut. "Setiap orang berhak mengembangkan diri melalui pemenuhan kebutuhan dasarnya, berhak memperoleh pendidikan dan memperoleh manfaat dari ilmu pengetahuan dan teknologi, seni dan budaya, demi meningkatkan kualitas hidupnya dan demi kesejahteraan umat manusia".

Sejalan dengan komitmen nasional, Indonesia sebagai salah satu Negara Anggota UNESCO berkomitmen kuat untuk memastikan pencapaian enam tujuan Pendidikan untuk Semua (EFA). Tujuan pendidikan adalah: 1) memperluas pendidikan dan pengasuhan anak usia dini peluang, 2) menjamin akses yang meluas dan setara ke pendidikan dasar, 3) memperluas kesempatan belajar seumur hidup, 4) memastikan peningkatan melek huruf dan melanjutkan pendidikan, 5) menjamin kesetaraan gender dalam pendidikan, dan 6) meningkatkan dan menjamin kualitas dan standar pendidikan.

Dalam mencapai tujuan tersebut, Indonesia telah menempuh sejumlah langkah untuk menyelaraskan perencanaan dan implementasi EFA di dalamnya pembangunan jangka menengah dan panjang yang lebih luas, dan sepenuhnya mengintegrasikan EFA ke dalam Indonesia visi pembangunan nasional kesejahteraan yang luas.

Namun, setelah 77 tahun merdeka dan 20 tahun sejak komitmen MDGs, masih banyak anak bangsa yang belum dapat menikmati pendidikan. Data menunjukkan masih besarnya proporsi penduduk yang belum dapat menikmati pendidikan atau 'tidak/belumpernah sekolah/belum tamat', atau memiliki ijazah SD.

Di Indonesia masih ada 16,62 persen penduduk yang tidak memiliki ijazah, di Jawa Tengah 14, 41 persen, dan di Kab. Magelang masih 15,94. Sementara, Pada ujung yang lain, proporsi penduduk yang dapat menikmati pendidikan tinggi sangat sedikit. Di Indonesia hanya 9,26 persen penduduk yang tidak memiliki ijazah sarjana, di Jawa Tengah hanya 6,87 persen, dan di Kab. Magelang hanya 6,72.

Perbedaan kualitas dan durasi pendidikan yang diterima anak-anak secara mendasar dapat mempengaruhi mata pencaharian mereka di masa depan. Anak-anak yang gagal menguasai keterampilan dasar lebih cenderung berakhir dalam pekerjaan yang tidak aman dan bergaji rendah, dibandingkan dengan anak-anak yang meninggalkan sekolah yang dilengkapi dengan keterampilan yang dibutuhkan di pasar tenaga kerja saat ini (Samer Al Samrrai, 2013).

Gillis, et. al (1992: 281-221) menemukan korelasi yang sangat kuat antar tingkat pendidikan yang dapat dicapai dengan pendapatan/penghasilan, baik secara individual maupun secara social. Juga ada hubungan yang sangat kuat antara pencapaian tingkat pendapatan dengan pendapatan nasional maupun regional. Potensi pendapatan ini dapat terkendala jika pendidikan dinikmati secara tidak merata. Pada umumnya masyarakatn yang mampu melanjutkan pendidikan adalah kelompok masyarakat yang lebih mampu.

Borjas (1996: 222-224) menemukan bahwa walaupun masyarakat faham bahwa membiayai pendidikan anak merupakan investasi yang menguntungkan, tetapai mereka belum tentu mampu berinvestasi, karena untuk bersekolah disamping ada biaya langsung (buku, peralatan sekolah, asrama dan transportasi) tetapi mereka sering mereka tidak mampu menanggung beban biaya tidak langsung, berupa hilangnya perluang memperoleh pendapatan karena waktunya untuk sekolah atau opportunity cost.

Akibatnya, penduduk yang berpendidikan rendah hanya akan diterima bekerja pada sector-sektor yang memberikan upah rendah. Dengan demikian ketimpangan pendidikan menjadi sumber peningkatan ketimpangan ekonomi. Oleh karena itu perlu didorong adanya kebijakan untuk pengarus-utamaan penurunan ketimpangan pendidikan.

Kajian kebijakan ini bertujuan untuk mengetahui hubungan antara ketimpangan pendidikan dengan rata-rata lama sekolah di Kabupaten Magelang. Terkait dengan tujuan ini, 


\section{Buletin Ekonomi}

penghitungan rata-rata lama sekolah (AYS) dan indek gini pendidikan (IGI). Selain itu, penelitian juga bertujuan untuk mengetahui hubungan antara rata-rata lama sekolah dan indeks Gini pendidikan antara tahun 2009 dan 2019. Sedangkan, motivasi penulisan ini adalah untuk melakukan pemantauan pelaksanaan program pendidikan untuk semua, dan dari hasil kajian adalah untuk menyusun rekomendasi kebijakan.

Thomas et al (2001) menghitung indeks pendidikan menggunakan data yang terkait dengan tingkat pendidikan di 85 negara antara 1960 dan 1990. Menurut penelitian ini, antara 1960 dan 1990, ketimpangan pendidikan menurun di banyak negara. Salah satu temuan terpenting dari ini Studi ini menemukan bahwa terdapat hubungan negatif antara rata-rata lama sekolah dan koefisien gini pendidikan.

Digdowiseiso (2010) menunjukkan bahwa: Pertama, dari sisi nasional, terjadi penurunan Gini pendidikan, Kedua, belajar dari kajian antar daerah menggambarkan bahwa seiring berjalannya waktu, daerah pedesaan memiliki ketimpangan pendidikan yang lebih tinggi dari pada perkotaan. Ketiga, studi antar gender menunjukkan bahwa penduduk perempuan memiliki ketimpangan pendidikan yang lebih tinggi dari populasi pria, Keempat, studi keterkaitan antara gender dan bidang menyatakan bahwa tingkat ketimpangan pendidikan penduduk perempuan dan laki-laki di pedesaan lebih tinggi dari itu di daerah perkotaan. Terakhir, dalam kaitan antara dua variabel, terdapat korelasi negatif antara Koefisien Gini pendidikan dan rata-rata lama sekolah.

Selanjutnya, ada beberapa kebijakan yang bisa diambil pemerintah untuk membantu upaya tersebut mencapai kesetaraan pendidikan di Indonesia. Pertama, pemerintah pusat, provinsi dan kabupaten harus mengambil atas tanggung jawab untuk mengelola setiap potensi sumber daya yang dimiliki, terutama sumber daya manusia. Misalnya, dengan meningkatkan kualitas dan kuantitas sekolah seperti guru kualitas dan kualifikasi, rasio siswa per guru, gaji guru dan insentif lainnya, sekolah fasilitas dan pemeliharaan, serta jumlah sekolah. Selain itu, mereka juga harus memberdayakan perempuan dan penduduk pedesaan dengan mengurangi angka melek huruf, menerapkan program pendidikan sembilan tahun, dan mengembangkan program pendidikan satu atap yang menggabungkan sekolah dasar dan sekolah menengah pertama sekolah menjadi satu gedung yang dekat dengan komunitas. Kedua, pemerintah pusat harus meningkatkan anggaran nasional di bidang pendidikan untuk meningkatkan kesetaraan pendidikan dan untuk memberikan dukungan keuangan kepada pemerintah provinsi dan kabupaten.

Selanjutnya, pemerintah pusat harus mengubah skema beasiswa untuk menjangkau anak-anak yang tidak mampu melanjutkan ke sekolah setelah menyelesaikan sekolah dasar. Kebijakan lainnya adalah pemerintah pusat harus meningkatkan biaya peluang untuk tidak bersekolah dengan memberikan subsidi tunai langsung kepada keluarga. Selain itu, pemerintah pusat harus mempromosikan pentingnya pendidikan. Terakhir, masyarakat harus berperan aktif sebagai pemimpin dalam pelaksanaannya pendidikan:

\section{METODE}

Kajian ini tergolong dalam jenis kajian kebijakan (policy issues paper). Prosedur analisis kebijakan disesuaikan dengan tahapan kebijakan serta komponen informasi yang dibutuhkan pada tahapan kebijakan tertentu. Berhubung kajian ini dilakukan pada saat kebijakan sedang dilaksanakan (policy action), maka menurut Dunn (1994: 72) prosedur analisis yang sesuai adalah pemantauan (monitoring). Selanjutnya, metode dan tehnik yang sesuai untuk pemantauan, antara lain sajian grafis (graphic displays) yang mencakup kurva Lorenz dan indek Gini (Dunn, 1994: 359-368). 


\section{Buletin Ekonomi}

Data yang dianalisis dalam kajian ini bersumber dari surve social ekonomi nasional (Susenas / BPS) tahun 2015 dan 2020, khusunya tabel: persentase penduduk usia 15 tahun ke atas menurut tipe daerah dan jenjang pendidikan tertinggi yang ditamatkan..

Pendidikan tertinggi yang ditamatkan adalah tingkat pendidikan yang dicapai seseorang setelah mengikuti pelajaran pada kelas tertinggi sesuai tingkatan sekolah dengan mendapatkan tanda tamat sekolah (ijazah)

Data akan dianalisis melalui sajian grafis, dan selanjutnya ditampilkan dan kurva Lorenz untuk menyajikan ketimpangan pendidikan secara virtual dan terakhir dihitung menggunakan rumus untuk menyajikan ketimpangan secara numerik.

Langkah pertama, menghitung kurva Lorenz dan koefisien gini pendidikan, adalah menghitung tahun sekolah pada enam jenjang pendidikan melalui rumus: :

- Tidak/Blm Pernah Sekolah/ Blm Tamat SD/MI : y1 = 0

- $\mathrm{SD} / \mathrm{MI}$

- SMP/MTs

- SMA/SMK/MA

- Perguruan tinggi
: $\mathrm{y} 2=\mathrm{y} 1+\mathrm{Cp}=\mathrm{Cp}$

: $\mathrm{y} 3=\mathrm{y} 2+\mathrm{Cr}=\mathrm{Cp}+\mathrm{Cr}$

: $\mathrm{y} 4=\mathrm{y} 3+\mathrm{Cs}=\mathrm{Cp}+\mathrm{Cr}+\mathrm{Cs}$

$: \mathrm{y} 5=\mathrm{y} 4+\mathrm{Ct}=\mathrm{Cp}+\mathrm{Cr}+\mathrm{Cs}+\mathrm{Ct}$

Dimana :

- Cp adalah siklus tidak tamat sekolah dasar (0 tahun)

- Cr adalah siklus sekolah dasar (6 tahun).

- Cs adalah siklus sekolah menengah pertama (3 tahun).

- Ct adalah siklus SMA (3 tahun).

- Co adalah siklus pendidikan tinggi (4 tahun)

Metode tidak langsung untuk membangun kurva Lorenz pendidikan, hasilnya ditunjukkan pada gambar 3, yaitu kombinasi antara persentase kumulatif tahun sekolah pada sumbu vertikal, dan persentase kumulatif populasi pada sumbu horizontal. Garis empat puluh lima derajat adalah garis pendidikan egaliter, mewakili persamaan kemerataan sempurna sekolah.

Langkah kedua, membangun kurva Lorenz. kurva Lorenz juga disebut sebagai metode penghitungan ketimpangan secara tidak langsung. Kurva Lorenz pendidikan, disajikan pada gambar 2, yaitu kombinasi antara persentase kumulatif tahun sekolah pada sumbu vertikal, ditunjukkan di S, dan persentase kumulatif populasi pada sumbu horizontal, ditunjukkan di Q.

Garis empat puluh lima derajat adalah garis pendidikan egaliter, mewakili persamaan sempurna sekolah. Dengan demikian, Gini pendidikan diperkirakan menggunakan metode tidak langsung sebagai perbandingan antara luas A dan luas OWQ.

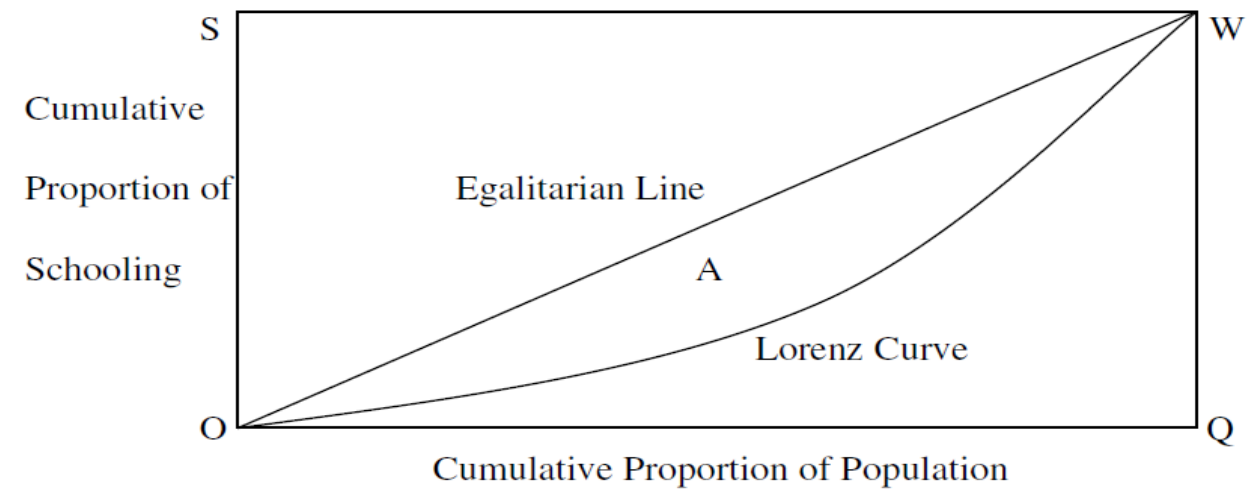

Gambar 1. Kurva Lorenz Pendidikan

Sumber: Digdowiseiso, 2010 


\section{Buletin Ekonomi}

Langkah ketiga, menghitung indek gini pendidikan, berdasarkan kurva Lorenz, melalui rumus Dunn (1994: 366) :

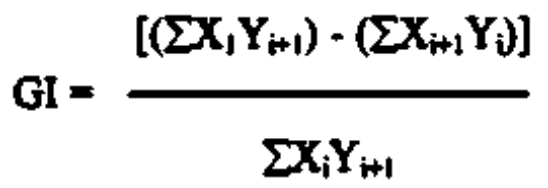

$\mathrm{X}_{\mathrm{i}}=$ distribusi persentase komulatif dari lama sekolah

$\mathrm{Y}_{\mathrm{i}}=$ distribusi persentase komulatif dari penduduk menurut pendidikan tertinggi yang ditamatkan.

\section{ANALISIS DAN PEMBAHASAN}

Pendidikan tinggi yang ditamatkan merupakan salah satu ukuran kualitas Sumber Daya Manusia (SDM). Semakin tinggi tingkat pendidikan yang dicapai, maka semakin tinggi pula kualitas sumber daya manusia yang dimiliki. Seseorang yang menamatkan pendidikannya hingga jenjang pendidikan tinggi, cenderung mempunyai pengetahuan yang luas serta keterampilan atau keahlian yang tinggi. Tingginya tingkat pendidikan juga dapat mencerminkan taraf intelektualitas suatu masyarakat.

Namun kondisi ideal tersebut belum tercapai di Kab. Magelang, sebagaimana disajikan dalam gambar 2, komposisi jumlah penduduk usia 15 tahun ke atas menurut tingkat pendidikan yang ditamatka. Terlihat bahwa masih besar proporsi penduduk yang tidak memiliki ijazah, dang sangat kecil proporsi penduduk yang memiliki ijazah sarjana. Pada tahun 2015, proporsi penduduk yang memiliki ijazah SD kebawah mencapai 55,74 persen, menurun pada tahun 2020 menjadi 44, 31 persen.

Secara umum, antara tahun 2015 dan 2020, ada perbaikan dalam 'angka pendidikan yang ditamatkan', dimana pada jenjang SD kebawah terjadi penurunan dan pada jenjang SMP keatas mengalami kenaikan. Penurunan besar terjadi pada kategori 'tidak / belum pernah sekolah'. Dan kenaikan yang besar pada kategori 'tamat perguruan tinggi'.

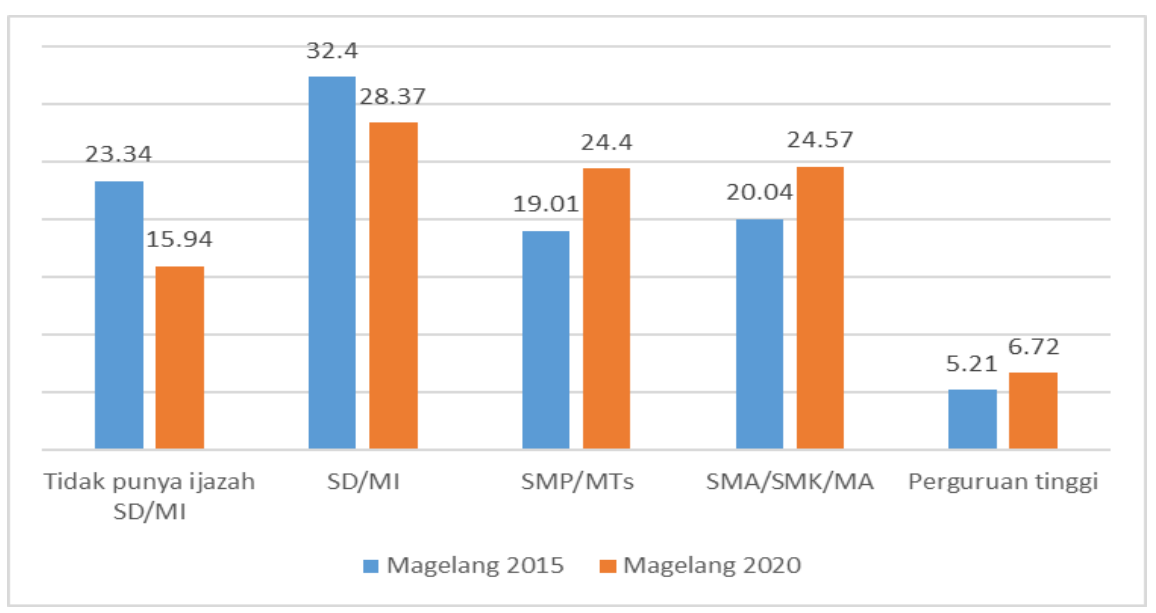

Gambar 2. Persentase Penduduk Umur 15 Tahun ke atas dan Pendidikan Tertinggi yang ditamatkan di Kab. Magelang tahun 2015 dan 2020 Sumber : Susenas, 2015 dan 2020

Berdasarkan data pada gambar 2, dilakukan penghitungan lama sekolah, pada enam jenjang pendidikan tersebut, maka dihasilkan kurva Lorenz sebagai berikut. Kurva Lorenz 


\section{Buletin Ekonomi}

pendidikan disebut juga sebagai metode tidak langsung untuk menghitung keimpangan pendidikan, sebagaimana disajikan pada gambar 3. Kurva menyajikan kombinasi antara persentase kumulatif tahun sekolah pada sumbu vertikal, dan persentase kumulatif populasi pada sumbu horizontal. Garis empat puluh lima derajat adalah garis pendidikan egaliter, mewakili persamaan kemerataan sempurna sekolah.

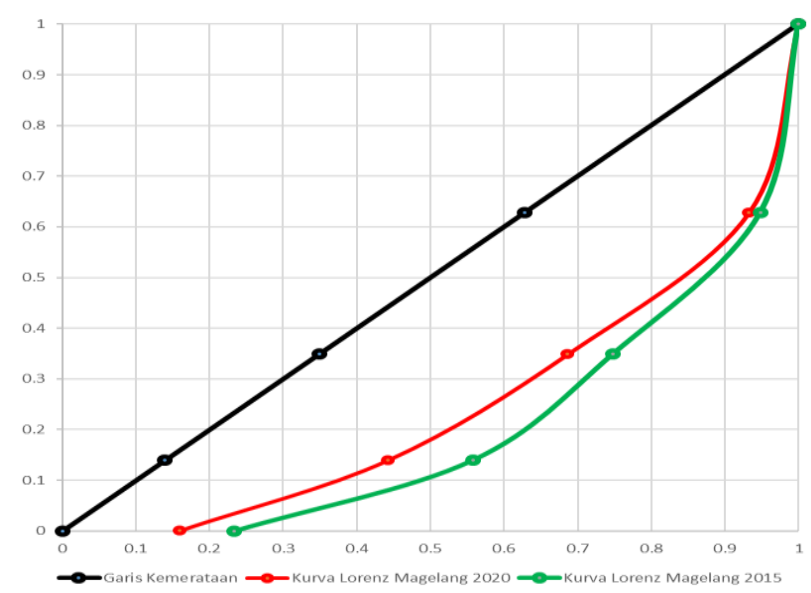

Gambar 3. Kurva Lorenz Pendidikan Kab. Magelang Tahun 2015 dan 2020 Sumber : Susenas, 2015 dan 2020

Dalam gambar ditunjukkan bahwa ada jarak yang jauh antara kurva Lorents dengan kurva kemerataan sempurna. Artinya, terjadi ketimpangan pendidikan yang cukup besar. Namun, ada kecenderungan untuk menyempit, sebagaimana ditunjukkan oleh pergeseran (shift) kurva warna hijau ke warna merah muda. Pergeseran ini menegaskan hipotesis bahwa semakin tinggi angka rata-rata sekolah akan menurunkan ketimpangan pendidikan. Hasil perhitungan indek gini pendidikan Kab. Magelang tahun 2015 sebesar 0.543 menurun pada tahun 2020 menjadi 0.469.

Di Jawa Tengah, komposisi jumlah penduduk usia 15 tahun ke atas menurut tingkat pendidikan yang ditamatkan disajikan dalam gambar 4. Terlihat bahwa masih besar proporsi penduduk yang tidak memiliki ijazah, dang sangat kecil proporsi penduduk yang memiliki ijazah sarjana. Pada tahun 2015, proporsi penduduk yang memiliki ijazah SD kebawah mencapai 56,27 persen, menurun pada tahun 2020 menjadi 44, 25 persen. Secara umum, antara tahun 2015 dan 2020, ada perbaikan dalam 'angka pendidikan yang ditamatkan', dimana pada jenjang SD kebawah terjadi penurunan dan pada jenjang SMP keatas mengalami kenaikan. Penurunan besar terjadi pada kategori 'tidak / belum pernah sekolah'. Dan kenaikan yang kecil pada kategori 'tamat perguruan tinggi'. 


\section{Buletin Ekonomi}

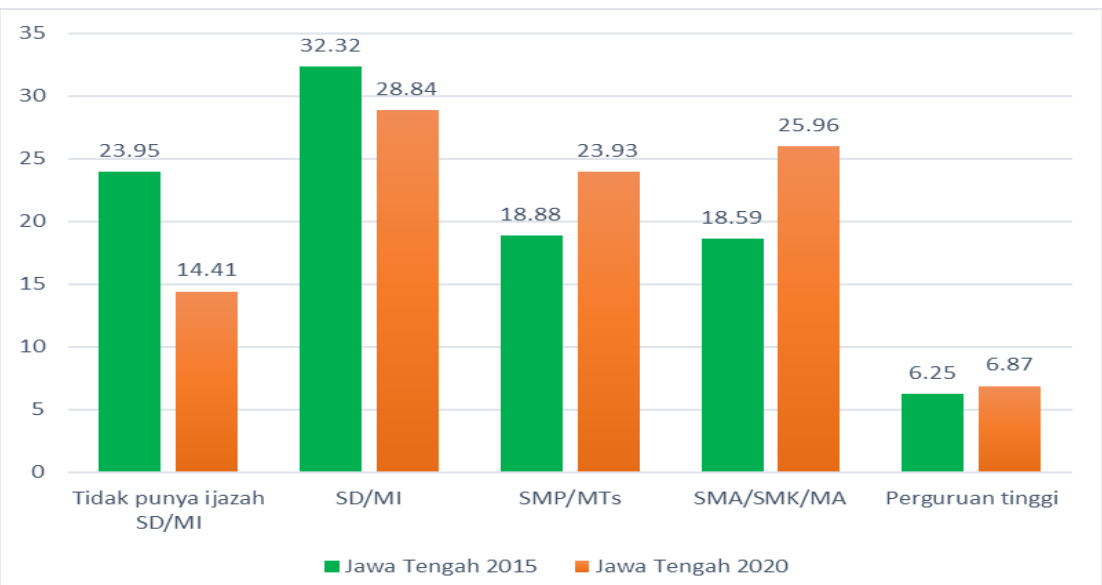

Gambar 4. Persentase Penduduk Umur 15 Tahun ke atas dan Pendidikan Tertinggi yang ditamatkan di Provinsi Jawa Tengah tahun 2015 dan 2020 Sumber : Susenas, 2015 dan 2020

Berdasarkan data pada gambar 4, dilakukan penghitungan lama sekolah, pada enam jenjang pendidikan tersebut, maka dihasilkan kurva Lorenz sebagai berikut. Kurva Lorenz pendidikan disebut juga sebagai metode tidak langsung untuk menghitung keimpangan pendidikan dan menyajikan secara grafis, sebagaimana disajikan pada gambar 5 .

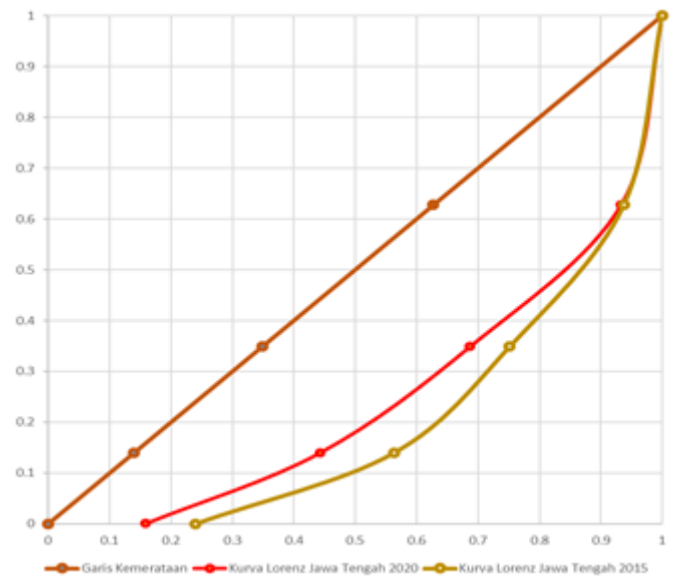

Gambar 5. Kurva Lorenz Pendidikan Prov. Jawa Tengah Tahun 2015 dan 2020 Sumber : Susenas, 2015 dan 2020.

Dalam gambar ditunjukkan bahwa ada jarak yang jauh antara kurva Lorents dengan kurva kemerataan sempurna. Artinya, terjadi ketimpangan pendidikan yang cukup besar. Namun, ada kecenderungan untuk menyempit, sebagaimana ditunjukkan oleh pergeseran (shift) kurva warna coklat muda ke warna merah muda. Pergeseran ini menegaskan hipotesis bahwa semakin tinggi angka rata-rata sekolah akan menurunkan ketimpangan pendidikan.

Hasil perhitungan indek gini pendidikan Prov. Jawa Tengah tahun 2015 sebesar 0.547 menurun pada tahun 2020 menjadi 0.456 . Secara nasional, komposisi jumlah penduduk usia 15 tahun ke atas menurut tingkat pendidikan yang ditamatkan disajikan dalam gambar 6 . Terlihat bahwa masih besar proporsi penduduk yang tidak memiliki ijazah, dang sangat kecil proporsi penduduk yang memiliki ijazah sarjana. Pada tahun 2015, proporsi penduduk yang memiliki ijazah SD kebawah mencapai 46.31 persen, menurun pada tahun 2020 menjadi 41.75 persen. Data menunjukkan bahwa penduduk yang berijazah SD ke bawah di tingkat nasional lebih rendah dari Prov. Jateng maupun Kab. Magelang. Secara umum, antara tahun 


\section{Buletin Ekonomi}

2015 dan 2020, ada perbaikan dalam 'angka pendidikan yang ditamatkan', dimana pada jenjang SD kebawah terjadi penurunan dan pada jenjang SMP keatas mengalami kenaikan. Penurunan besar terjadi pada kategori 'tidak / belum pernah sekolah'. Dan kenaikan yang cukup besar pada kategori 'tamat perguruan tinggi'.

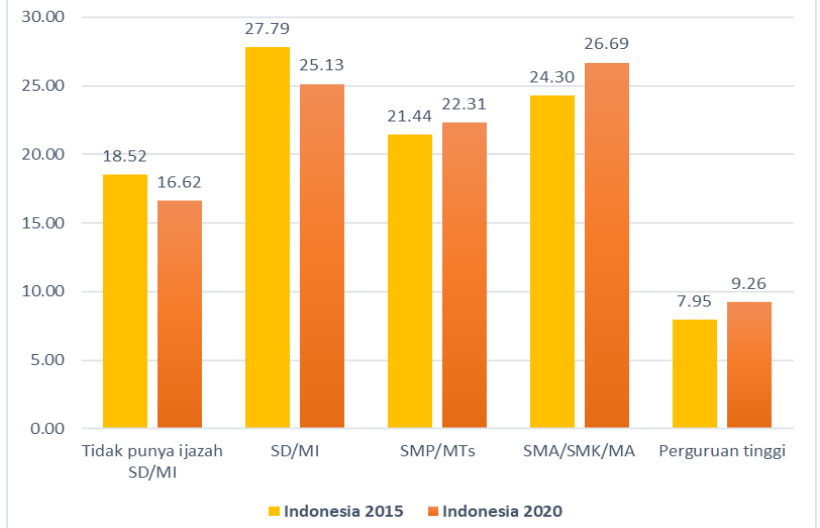

Gambar 6. Persentase Penduduk Umur 15 Tahun ke atas dan Pendidikan Tertinggi yang ditamatkan nasional tahun 2015 dan 2020

Sumber : Susenas, 2015 dan 2020

Berdasarkan data pada gambar 6, dilakukan penghitungan lama sekolah, pada enam jenjang pendidikan tersebut, maka dihasilkan kurva Lorenz sebagai berikut. Kurva Lorenz pendidikan disebut juga sebagai metode tidak langsung untuk menghitung keimpangan pendidikan dan menyajikan secara grafis, sebagaimana disajikan pada gambar 7 .

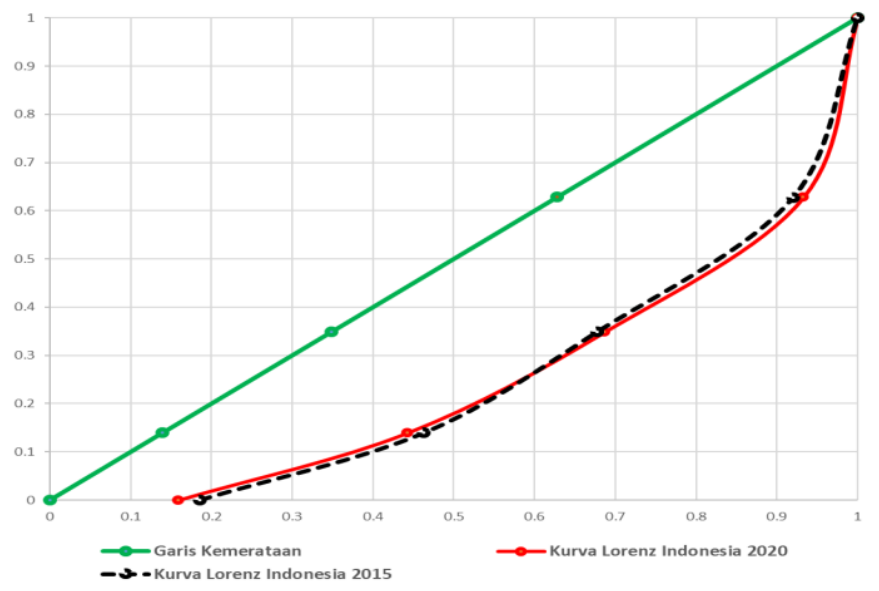

Gambar 7. Kurva Lorenz Pendidikan Indonesia Tahun 2015 dan 2020 Sumber : Susenas, 2015 dan 2020

Dalam gambar ditunjukkan bahwa ada jarak yang jauh antara kurva Lorents dengan kurva kemerataan sempurna. Artinya, terjadi ketimpangan pendidikan yang cukup besar. Dan, hanya ada sedikit kecenderungan untuk menyempit, sebagaimana ditunjukkan oleh pergeseran (shift) kurva warna hitam ke warna merah muda. Pergeseran ini menegaskan hipotesis bahwa semakin tinggi angka rata-rata sekolah akan menurunkan ketimpangan pendidikan.

Hasil perhitungan indek gini pendidikan secara nasional tahun 2015 sebesar 0.4693 menurun pada tahun 2020 menjadi 0.430. Dalam gambar 8 ditunjukkan perbandingan 


\section{Buletin Ekonomi}

kurva Lorents Pendidikan Indonesia, Jawa Tengah dan Magelang. Nampak bahwa kurva nasional lebih dekat ke garis egaliter.

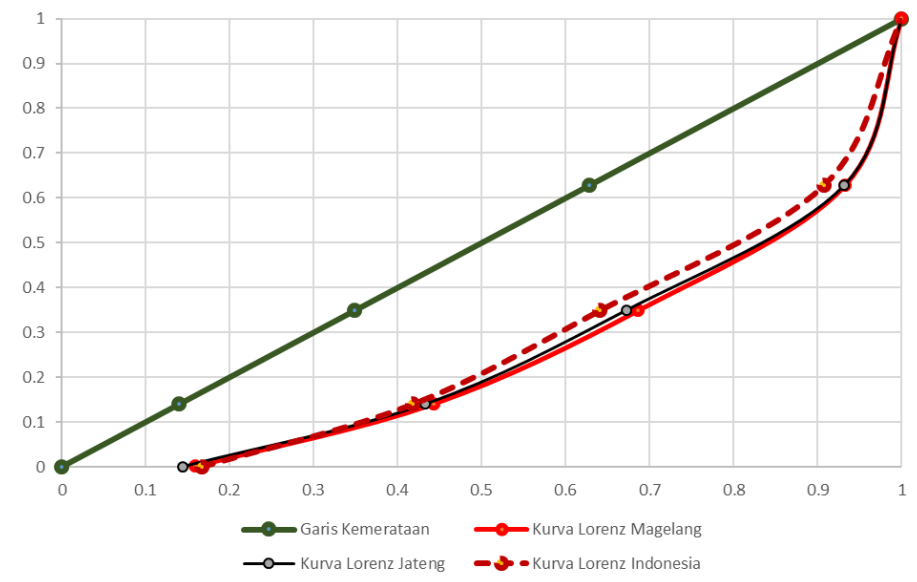

Gambar 8. Perbandingan Kurva Lorenz Pendidikan Indonesia, Jawa Tengah dan Magelang Tahun 2015 dan 2020

Sumber : Susenas, 2015 dan 2020.

\section{KESIMPULAN DAN SARAN}

\section{Kesimpulan}

1. Hasil perhitungan indek gini pendidikan Kab. Magelang tahun 2015 sebesar 0.547 menurun pada tahun 2020 menjadi 0.469. Prov. Jawa Tengah tahun 2015 sebesar 0,546 menurun pada tahun 2020 menjadi 0.456. Nasional tahun 2015 sebesar 0.4693 menurun pada tahun 2020 menjadi 0.430. Dari nilai indek gini tersebut kegiga wilayah pengamatan dapat digolongkan berada dalam ketimpangan 'sedang'. Hasil perhitungan indeks gini menunjukan bahwa Indonesia lebih merata daripada Jawa Tengan, dan Magelang paling tidak merata.

2. Hubungan negatif ditemukan antara rata-rata tahun sekolah dan indeks Gini pendidikan. hubungan positif ditemukan antara tingkat kenaikan rata-rata tahun sekolah dan penurunan indeks Gini pendidikan.

\section{Saran}

Dengan demikian, rekomendasi kebijakan yang diajukan adalah peningkatan rata-rata lama sekolah, sebagai berikut:

1. Menempatkan pendidikan sebagai prioritas pembangunan nasional dan daerah, dengan menempatkan perluasan akses layanan pendidikan, sebagai super prioritas pembangunan daerah.

2. Menempatkan pengurangan ketimpangan pendidikan sebagai indicator sasaran pembangunan nasional dan daerah. Dimana indicator ini dibangun dengan basis data 'persentase penduduk umur 15 tahun ke atas dan pendidikan tertinggi yang ditamatkan' yang merupakan indicator benefit pendidikan.

3. Menerapkan dua strategi pengurangan ketimpangan pendidikan yaitu, pertama: menurunkan beban biaya pendidikan yang harus ditanggung masyarakat. Kedua, meningkatkan pendapatan pendapatan. Dua strategi ini adalah untuk mengatasi, adanya dua jenis beban biaya pendidikan, yaitu biaya langsung (sumbangan pendidikan, transportasi, buku dan perlengkapan sekolah, serta biaya hidup selama sekolah). Dan biaya tidak langsung (opportunity cost) berupa hilangnya peluang untuk memperoleh pendapata karena tidak bekerja demi sekolah. 


\section{Buletin Ekonomi}

4. Melaksanakan program-program untuk pengurangan beban, pengembangan sekolah satu atap, perluasan kelompok belajar, bea siswa miskin, BLT bagi peserta Kejar (Paket A, B, C), pembangunan infrastruktur: jalan, jembatan dan transportasi;

5. Melaksanakan program-program untuk peningkatan pendapatan, meliputi programprogram untuk meningkatkan pertumbuhan ekonomi inklusif, antara lain pelatihan tenaga kerja, perluasan kesempatan kerja utamanya pada sector-sektor yang membutuhkan input iptek, antara lain teknoligi informatika dan telekomunikasi, pengembangan barbasis TIK, antara lain e-commerce dan penerapan teknologi finansial, UKM, pengembangan ekeonomi kretif untuk memberi wadah para pemuda-pemuda millennial, pembangunan pedesaan (padat karya), penanggulangan kemiskinan.

\section{DAFTAR PUSTAKA}

Borjas, George J (1996), Labor Economic, New York: The McGraw-Hill Companies. Inc.

Digdowiseiso, Kumba (2010), Measuring Gini Coefficient Of Education: The Indonesian Cases, Munich Personal RePEc Archive, https://mpra.ub.uni-muenchen.de/19865/, pada tanggal 3 Februari 2021

Dunn, William N, (1994), Public Policy Analysis, New Jersey: Prentice Hall, Inc.

Evi Syuriani Harahap, Indra Maipita, M. Fitri Rahmadana (2020), Determinant Analysis of Education Inequalities in Indonesia, BIRCI-Journal Volume 3, No 2, May 2020, www.bircu-journal.com/index.php/ birci, pada tanggal 1 Februari 2021

Gillis, Malcolm; Perkins, Dwigth H.; Rommer, Michael; Snodgrass, Donald R (1992), Economic of Development, London: WW Norton \& Company

Samarrai, Samer Al (2013), In Indonesia, Tackling Education Inequality Through Better Governance, https://blogs.worldbank.org/, pada tanggal 31 Maret 2021

Vinod Thomas, Yan Wang, and Xibo Fan (2010), Measuring Education Inequality: Gini Coefficients of Education, http://www.worldbank.org/devforum/, pada tanggal 6 Februari 2021. 